\title{
MELIHAT KEAMANAN MARITIM INDONESIA DARI IDE POROS MARITIM
}

\author{
Muhammad Edrian ${ }^{1}$
}

Abstrak: Ide Poros Maritim Dunia yang sudah dijalankan oleh pemerintah Indonesia selama dua tahun pada kenyataanya belum menaungi aspek keamanan maritim sebagai prioritas dimana hal tersebut harus dibarengi dengan pembangunan kekuatan Angkatan Laut sebagai elemen pendukung utama. Mengingat adanya keterkaitan antara isu keamanan maritim dengan upaya menciptakan good maritime governance, sudah selayaknya pemerintah Indonesia menjadikan keamanan maritim sebagai prioritas dalam kebijakan maritim yang dikeluarkan. Mengingat dalam prakteknya Indonesia belum memilikiacuan yang jelas dalam membuat kebijakan maritim, pemerintah perlu menyusun suatu doktrin yang berfungsi sebagai pegangan dalam setiap pembuatan kebijakan maritim. Selanjutnya, pemerintah harus membangun Maritime Domain Awareness (MDA) sebagai wawasan agar mampu meningkatkan kepedulian seluruh instrumen negara dalam berbagai sektor dalam isu maritim. Terakhir, pemerintah baru bisa menaruh perhatian dalam pembangunan sea power dimana pembangunan kekuatan Angkatan Laut merupakan salah satu agenda utama.

Tulisan ini bermaksud untuk menjelaskan tiga elemen yang secara urut harus dimiliki oleh pemerintah Indonesia dalam ide Poros Maritim Dunia agar dapat menghadapi isu keamanan maritim dengan baik. Pertama, pemerintah harus lebih dulu menciptakan doktrin maritim sebagai dasar pembuatan kebijakan. Selanjutnya, pemerintah harus membangun MDA sebagai wawasan bagi setiap elemen negara agar bersinergi mendukung pemerintah. Terakhir, setelah kedua elemen tersebut terpenuhi, pemerintah bisa mulai berfokus dalam membangun sea power sebagai instrumen dala menghadapi isu keamanan maritim..

\section{Kata Kunci: Keamanan Maritim, Doktrin Maritim, Maritime Domain Awareness, Sea Power}

\section{PENDAHULUAN}

Setelah resmi dilantik sebagai presiden Republik Indonesia, Joko Widodo (Jokowi) menegaskan niatnya untuk mewujudkan pemerintahan yang berorientasi pada bidang maritim dan menjadikan Indonesia sebagai negara maritim terkemuka dunia (FKP Maritim, 2014). Ide yang kemudian dikenal sebagai "Poros Maritim Dunia" ini terdiri dari lima elemen yang terdiri dari (i) pembangunan kembali budaya maritim Indonesia, (ii) menjaga dan mengelola sumber daya laut dengan fokus membangun kedaulatan laut melalui pengembangan industri perikanan, (iii) mendorong pengembangan infrastruktur dan konektivitas maritim dengan membangun tol laut $^{2}$, pelabuhan laut dalam, logistik dan

\footnotetext{
1 Pemerhati pertahanan yang dapat dihubungi di muhammadedrian93@yahoo.com
}

2. Yang dimaksud dengan Tol Laut adalah sistem pengiriman barang menggunakan kapal-kapal kargo yang menjangkau seluruh wilayah Indonesia. industri perkapalan, serta pariwisata maritim, (iv) melakukan diplomasi maritim yang bertujuan menghilangkan berbagai sumber konflik di laut, dan (v) membangun kekuatan dan pertahanan maritim untuk menjaga kedaulatan dan kekayaan maritim serta menjaga keselamatan, pelayaran, dan keamanan maritim (Antara News, 2014).

Dalam praktiknya, ide Poros Maritim Dunia memang lebih banyak membahas sisi pembangunan ekonomi berbasis maritim ${ }^{3}$. Tetapi, ide Poros Maritim Dunia yang diusung oleh Jokowi sebenarnya harus memiliki cakupan yang lebih luas dari sisi ekonomi. Salah satu sisi yang kurang dan seharusnya menjadi perhatian dalam ide tersebut adalah keamanan maritim dimana hal tersebut merupakan tanggung jawab yang harus diperhatikan dan diemban oleh Indonesia

3.Yang dimaksud dengan pembangunan ekonomi berbasis maritim bisa mengandung berbagai interpretasi, tetapi esensinya adalah menjadikan laut sebagai sumber, media, dan orientasi dalam 
dengan cara melibatkan kekuatan militer dalam hal ini Angkatan Laut (TNI AL). Padahal, keamanan maritim adalah parameter kunci dari keberhasilan sebuah pemerintah dalam menjalankan good maritime governance dimana negara mampu meminimalisir resiko, menangani permasalahan, serta melindungi warganya dan kepentingan nasionalnya dari segala ancaman dalam bidang maritim (Jurnal Maritim, 2014).

Berkaitan dengan hal tersebut, ada beberapa kelemahan yang terdapat dalam ide Poros Maritim Dunia sehingga berpotensi menjadikan keamanan maritim sebagai isu yang kontra-produktif. Pertama, ketidakseimbangan dalam ide Poros Maritim Dunia yang terlalu menekankan pada pendekatan kedalam (inward looking), yang sering diasosiasikan sebagai pembangunan ekonomi berbasis maritim, sehingga cenderung kurang memperhatikan pendekatan keluar (outward looking), yang sering diasosiasikan sebagai upaya pembangunan sea power. Selanjutnya adalah kurangnya penglibatan dan pemahaman unsur Maritime Domain Awareness (MDA) sebagai wawasan dan pengetahuan sehingga menimbulkan ketidakjelasan, baik dala teori maupun aplikasi, dalam ide Poros Maritim Dunia mengingat aspek maritim memiliki cakupan yang sangat luas. Terakhir, belum adanya doktrin yang berfungsi sebagai pakem dasar bagi para pembuat kebijakan. Selain berfungsi sebagai inti yang menggerakan para pembuat kebijakan, doktrin juga berfungsi sebagai alat bantu dalam menghadapi kompleksitas yang selalu dihadapi para pembuat kebijakan dalam proses pengambilan keputusan.

\section{PENELITIAN}

Pendekatan penelitian yang digunakan dalam tulisan ini adalah dengan menggunakan pendekatan kualitatif yang digunakan dengan tujuan untuk memahami fenomena yang menjadi objek penelitian untuk kemudian disajikan secara deskriptif. Secara umum, penelitian kualitatif terdiri dari tiga tahap. Tahap pertama adalah dimulai dengan langkah mengumpulkan, menelaah, dan mereduksi seluruh data yang tersedia dan didapatkan dari berbagai sumber untuk kemudian dianalisis. Tahap kedua adalah penyajian data dimana data yang sudah direduksi dan dianalisis agar dapat menjadi dasar bagi langkah selanjutnya yang akan diambil apakah melanjutkan analisis atau membuat kesimpulan. Tahap ketiga merupakan pengambilan kesimpulan (Idrus, 2007).

Tipe penelitian kualitatif yang digunakan didalam tulisan ini adalah studi kasus yang berfokus pada menjelaskan suatu kasus atau fenomena. Selain itu, tulisan ini juga menggunakan teknik analisis data bertipe eksplanatif dimana tulisan ini bermaksud untuk membuat penjelasan secara sistematis, faktual, dan akurat mengenai suatu masalah atau fenomena tertentu dengan mengumpulkan data yang sesuai dengan keadaan yang sebenarnya dan menyajikan serta menganalisis data tersebut untuk memperoleh informasi yang diperlukan sehingga dapat ditarik kesimpulan berupa gambaran jelas dan komprehensif mengapa suatu fenomena terjadi dan membuat suatu rekomendasi jika diperlukan (Suryabrata, 2003).

\section{PEMBAHASAN}

Tulisan ini bermaksud mendeskripsikan tiga unsur yang menjadi kelemahan dalam ide Poros Maritim Dunia dimana ketiga unsur tersebut merupakan elemen esensial bagi negara dalam menghadapi isu keamanan maritim sebagai bagian dari kebijakan maritim, terutama jika sebuah negara ingin membangun perekonomian berbasis maritim seperti Indonesia. Secara bertahap, sebuah negara harus memiliki doktrin maritim sebagai kerangka pembuatan kebijakan sekaligus cara pandang negara dalam keamanan maritim. Lalu, sebuah negara harus memiliki pemahaman komprehensif mengenai seluruh aspek isu keamanan maritim dan menyebarkannya kepada para pembuat kebijakan dan pemangku kepentingan dalam keamanan maritim. Terakhir, barulah negara dapat membangun sea power sebagai bentuk pengimplementasian dari dua unsur tersebut. 




\subsection{DOKTRIN KONSESUS \\ MARITIM \\ SEBAGAI}

Ketika

Jokowi

pertama

kali membicarakan ide Poros Maritim Dunia dihadapan para pemimpin negara lain yang hadir dalam KTT Asia Timur (East Asia Summit/EAS) di Naypitaw, Myanmar, pada bulan November 2014, banyak pihak yang menganggap bahwa Jokowi telah melontarkan penjabaran tentang Doktrin Maritim Indonesia. Hal ini tidak tepat karena sebenarnya yang dijabarkan oleh Jokowi di EAS baru merupakan gambaran mengenai lima misi yang diusung oleh Jokowi yang bermuara kepada visi menjadikan Indonesia menjadikan Indonesia sebagai negara yang terkemuka dalam bidang maritim. Dengan demikian, diperlukan penjelasan mengenai apa disebut dengan Doktrin Maritim dan kaitannya dengan keamanan maritim.

Secara harfiah, doktrin dapat diartikan sebagai kepercayaan atau pemikiran yang diterima sebagai pengatur dan dengan demikian berfungsi sebagai penyedia kerangka berpikir yang menuntun kelompok yang meyakininya. Sementara yang dimaksud dengan maritim adalah hal yang berkaitan dengan laut serta segala aktifitas yang behubungan erat dengannya dan menggambarkan segala objek mengenai laut. Dari dua pengertian tersebut, bisa ditarik bahwa doktrin maritim merupakan "Pemikiran mengenai cara terbaik dalam menyelesaikan suatu masalah yang menuntun para penganutnya dalam menghadapi masalah maritim dan instrumen marim didalamnya". Doktrin maritim sendiri berisikan prinsip-prinsip dimana suatu negara kekuatan mengarahkan tindakan-tindakannya untuk mendukung kepentingan nasional dalam bidang maritim dimana prinsip-prinsip tersebut diambil dari pengalaman suatu negara pada isu maritim dalam kancah nasional maupun internasional (Salim, 2014).

Doktrin merupakan suatu pedoman yang bersifat mendasar yang diyakini kebenarannya untuk menghadapi sesuatu masalah yang aplikasinya tergantung dari situasi yang berlaku pada saat itu. Sebuah doktrin akan terbentuk melalui proses penalaran dengan dipengaruhi oleh beberapa konsepnya. Konsep dalam doktrin sendiri berasal dari kesimpulan terhadap suatu fakta atau fenomena yang dihadapi secara langsung. Dalam praktiknya, doktrin kemudian diajarkan serta disebarluaskan dimana pelaksanaannya harus didasarkan pada pemahaman yang memadai mengenai kondisi yang berlangsung pada saat itu (Salim, 2014). Dan karena doktrin merupakan cara berpikir dalam menghadapi masalah alih-alih cara dalam menyelesaikan masalah, doktrin merupakan sesuatu yang fleksibel dan dapat berganti kapan saja tergantung dari dinamika kondisi dan situasi pada tempat dimana penganutnya berada (Indian Navy, 2016).

Berkali-kali telah didengungkan bahwa Indonesia adalah negara maritim namun tanpa sebuah implementasi yang jelas. Implementasi tersebut memerlukan kesamaan visi dari seluruh komponen bangsa dimana visi yang sama dapat terbangun jika terjadi perubahan paradigma secara fundamental. Perubahan ini dapat mulai dilakukan dengan merumuskan sebuah doktrin maritim yang berperan sebagai pedoman dalam penyamaan visi maritim. Para pembuat kebijakan harus memahami dan menyatakan bahwa Indonesia merupakan sebuah negara maritim baik dilihat dari konteks geografis maupun historis ${ }^{4}$. Untuk mewujudkan hal tersebut, secara umum bangsa Indonesia harus lebih dulu berubah menjadi bangsa yang berwawasan maritim. Disamping itu, secara khusus mutlak untuk disadari bahwa dalam membangun bangsa ini diperlukan pembangunan sea power dengan armada Angkatan Laut (TNI AL) yang kuat sebagai elemen utama, serta adanya suatu

\footnotetext{
4. Pemahaman dalam konteks geografis berorientasi pada wujud Indonesia sebagai negara kepulauan yang wilayahnya didominasi oleh laut dan terletak diantara perairan yang memiliki nilai strategis bagi banyak pihak yaitu Samudra Pasifik, Samudra Hindia, dan Laut Tiongkok Selatan, sedangkan pemahaman dalam konteks historis berorientasi pada sejarah masa lalu Indonesia yang pernah menjadi sebuah negara maritim yang kuat pada masa Kerajaan Sriwijaya dan Kerajaan Majapahit.
} 
kerjasama yang kuat antar pemangku kepentingan maritim dalamisu maritim.

Jika nanti terwujud, Doktrin Maritim Indonesia harus memuat penjelasan dan gambaran komprehensif mengenai bagaimana Indonesia seharusnya menyiapkan diri dalam masa damai maupun perang, khususnya dalam isu keamanan maritim. Doktrin ini akan menjelaskan posisi TNI AL sebagai garda terdepan dalam menghadapi isu keamanan maritim serta perannya dalam kebijakan maritimpemerintah guna mensinergikan lembaga kemaritiman ${ }^{5}$ lain yang ada. Doktrin ini juga akan menggariskan bagaimana peran dan kontribusi TNI AL dalam negara secara menyeluruh dan bersama-sama elemen lain dalam melindungi kepentingan nasional Indonesia. Disamping itu doktrin maritim juga menjelaskan bentuk peran aktif TNI AL serta lembaga kemaritiman lain dalam membangun kekuatan maritim di Indonesia menuju negara maritim yang besar.

\subsection{MEMAHAMI LAUT MELALUI MDA}

"Control of the seas means security. Control of the seas means peace. Control of the seas can mean victory. The United States must control the sea if it is to protect our security."

(John F. Kennedy)

Konsep Maritime Domain Awareness (MDA) pada intinya merupakan pemahaman secara komprehensif mengenai aspek-aspek yang berhubungan dengan maritim dan mempengaruhi keamanan, keselamatan, ekonomi, atau lingkungan, dan juga akan menjadi kunci dalam menyusun kebijakan kelautan di dunia serta menjamin keselamatan perdagangan maritim (Marsetio, 2013). Dalam rangka menjamin keamanan maritim, diperlukan kemampuan dan kekuatan negara yang cukup memadai untuk menangkal segala bentuk ancaman yang mengganggu kestabilan keamanan maritim. Dan hal itu dapat diawali dengan baik jika negara memiliki pemahaman yang baik mengenai laut dan membangun orientasi dalam isu keamanan maritim dari skala internasional.

Menurut Geoffrey Till, laut memiliki empat fungsi utama yang dapat memberikan

5. Yang dimaksud dengan lembaga kemaritiman adalah lembaga yang murni berfokus pada kemaritiman atau lembaga yang sejatinya tidak berfokus pada kemaritiman tetapi ikut dilibatkan dalam proses pembentukkan kebijakan maritim. keuntungan bagi negara pada masa damai maupun perang (Till dalam Ho \& Bateman, 2012). Pertama, laut sebagai sumber daya dimana laut merupakan tempat berkumpulnya sumber daya, baik hayati maupun energi, yang berperan penting bagi negara seperti biota laut, minyak bumi, dan gas alam. Kedua, laut sebagai jalur transportasi dan perdagangan yang berarti laut merupakan unsur penghubung utama dari aktivitas perdagangan yang merupakan bagian dari globalisasi serta dianggap dapat meningkatkan perdamaian dan kemakmuran dalam skala global. Ketiga, laut sebagai media informasi dan penyebaran ide. Meningkatnya arus aliran barang seringkali diikuti dengan pertukaran informasi atau ilmu pengetahuan baru dari berbagai belahan dunia meskipun saat ini fungsi tersebut telah tergerus oleh perkembangan teknologi informasi. Keempat, laut sebagai atribut kekuasaan dimana negara menggunakan laut sebagai instrumen dalam upaya memenuhi kepentingan nasional mereka.

Sejak dahulu, domain maritim, terutama yang berkaitan dengan wilayah perairan internasional, dikenal sebagai hal yang bersifat anarki dimana terdapat berbagai kepentingan negara dan lemahnya pengawasan terhadap segala aktivitas yang dilakukan di laut. Oleh karena itu, aspek ancaman yang diperhatikan dalam keamanan maritim masih merupakan ancaman tradisional seperti sengketa batas teritorial (Raymond \& Morriën dalam Herbert-Burns, Bateman, \& Lehr, 2009). Tetapi sejak peristiwa penyerangan terhadap kapal perusak Angkatan Laut Amerika Serikat USS Cole dan 11 September $^{6}$, aspek ancaman dalam keamanan maritim bergeser kepada ancaman kontemporer yang melibatkan aktor nonnegara seperti pembajakan dan penyelundupan. Hal ini disebabkan karena anarki di laut telah menciptakan vulnerabilitas yang pada perkembangannya dimanfaatkan oleh para pelaku kejahatan untuk melakukan kejahatan melalui laut seperti pembajakan atau terorisme (Raymond \& Morriën dalam Herbert-Burns, Bateman, \& Lehr, 2009).

\footnotetext{
6 . Peristiwa yang juga dikenal dengan kependekan 9/11 ketika menara World Trade Centre dan gedung Pentagon di Amerika Serikat ditabrak oleh pesawat yang sebelumnya telah dibajak.
} 




Di kawasan Asia, keamanan maritim merupakan isu yang muncul sebagai tuntutan perkembangan kawasan tersebut sebagai episentrum dari perdagangan dunia yang ditandai dengan tiga fenomena yaitu; (i) meningkatnya volume perdagangan antar negara, (ii) permintaan sumber daya laut yang semakin meningkat, (iii) meningkatnya jumlah armada kapal dagang (Ho \& Raymond, 2005). Kondisi tersebut membuat laut menjadi instrumen paling krusial dan paling diandalkan negara-negara di kawasan Asia sebagai jalur perdagangan, media transportasi kapal, dan media pemanfaatan sumber daya laut. Hal ini masih ditambah dengan adanya tekanan berupa konsesus dari masyarakat internasional terhadap negara-negara Asia untuk selalu berupaya menjaga keteraturan dan keamanan dari wilayah laut mereka dari berbagai ancaman yang dapat mengganggu segala aktivitas di wilayah laut kawasan tersebut (Ho \& Raymond, 2005).

Bagi Indonesia, keamanan maritim menjadi isu penting untuk diperhatikan mengingat nilai strategis yang dimiliki Indonesia melihat posisi geografis Indonesia yang terletak diantara dua benua yaitu Asia dan Australia. Nilai strategis tersebut bukan hanya terletak pada aspek perdagangan, tetapi juga terletak pada aspek pelayaran mengingat International Maritime Organization $(\mathrm{IMO})^{7}$ telah mengakui wilayah laut Indonesia, yang terbagi kedalam tiga bagian yang dinamakan Alur Laut Kepulauan Indonesia

7. IMO adalah badan khusus dari PBB yang menangani tentang hal yang berkaitan dengan aturan keselamatan dan keamanan pelayaran kapal di seluruh dunia.
$(\mathrm{ALKI})^{8}$, sebagai jalur pelayaran bagi kapalkapal asing dimana hal tersebut juga diatur dalam Peraturan Pemerintah Nomor 37 Tahun $2002^{9}$ (Djalal dalam Ho \& Bateman, 2012). Lebih lanjut, Indonesia juga wajib menjaga wilayah lautnya dari segala ancaman mengingat status Indonesia sebagai negara yang keamanan wilayah lautnya merupakan katalisator bagi kestabilan maritim di kawasan Asia Tenggara (Suwarto, 2013).

Pada pengaplikasiannya, MDA merupakan hal yang agak berbeda dengan doktrin maritim yang hanya eksklusif dipahami oleh para pembuat kebijakan maritim. Selain harus dipahami oleh para pembuat kebijakan, MDA ini nantinya merupakan wawasan yang juga harus diketahui dan dipahami oleh masyarakat sebagai sebuah kesadaran agar masyarakat dapat ikut bahu membahu bersama dengan para pembuat kebijakan dalam mendukung kebijakan maritim. Partisipasi dan dukungan masyarakat merupakan hal yang penting karena hal tersebut menunjukkan bahwa kebijakan maritim yang diambil oleh pemerintah bukanlah sebuah produk dari kepentingan pemerintah semata melainkan kepentingan seluruh elemen negara termasuk masyarakat sehingga kebijakan maritim yang diambil akan menciptakan sinergi antara pemerintah dan masyarakat alih-alih menimbulkan antipati atau kebingungan dalam masyarakat.

\subsection{MEMBANGUN SEA POWER MULAI DARI MILITER}

"Control of the sea by maritime commerce and naval supremacy means predominance influence in the world and is the chief among the merely material elements in the power and prosperity of nations."

8. ALKI memiliki tiga jalur yaitu ALKI I yang melintasi Laut Natuna, Selat Karimata, Laut Jawa, dan Selat Sunda, ALKI II yang melintasi Selat Makassar, Laut Flores, dan Selat Lombok, serta ALKI III yang melintasi Laut Maluku, Laut Seram, Laut Banda, Selat Ombai, dan Laut Sawu.

9. Peraturan Pemerintah tersebut membahas tentang hak dan kewajiban kapal dan pesawat udara asing dalam melaksanakan hak lintas alur laut kepulauan melalui alur laut kepulauan yang ditetapkan. 
(Alfred Thayer Mahan)

Istilah sea power dipopulerkan oleh seorang laksamana terkemuka Angkatan Laut Amerika Serikat (AS) pada era Perang Saudara Amerika bernama Alfred Thayer Mahan. Mahan mendeskripsikan sea power sebagai kemampuan negara untuk melindung kepentingan politik, ekonomi, dan militernya dengan menggunakan laut. Lebih lanjut, Mahan juga menyebutkan empat prinsip yang terkandung didalam sea power yaitu naval power, ocean science, ocean industry, and ocean commerce. Sedangkan menurut Sir Julian Corbett, sea power bukan hanya membahas mengenai apa yang bisa negara lakukan di laut, tetapi juga mencakup seberapa efektif tindakan suatu negara di laut dapat berdampak bagi aspek daratan. (Till, 2004). Corbett mengatakan:

"Since men live upon the land and not upon the sea, great issues between nations at war have always been decided - except in the rarest cases - either by what your army can do against your enemy's territory and national life, or else by fear of what the fleet makes it possible for your army to do"

(Till, 2004).

Berdasarkan penjelasan dari Mahan dan Corbett, sea power tidak melulu membahas mengenai kekuatan militer di laut melainkan juga mencakup aspek-aspek seperti persaingan perdagangan, persaingan militer, dan diplomasi. Meskipun aspek-aspek tersebut saling berkaitan dan bersifat saling melengkapi, kekuatan militer tetap merupakan dasar dari sea power karena militer merupakan elemen pelindung kepentingan nasional negara dalam hal apapun (Rubel, 2012). Sebagai contoh adalah Tiongkok yang sebelum mendeklarasikan keinginannya untuk membangun ekonomi berbasis maritim sudah lebih dulu membangun kekuatan militernya, terutama Angkatan Laut, secara bertahap.

Menurut Mahan, ada enam syarat yang harus dipenuhi oleh suatu negara jika negara tersebut ingin membangun sea power. Keenam syarat itu adalah posisi geografis, atribut fisik pendukung (kekayaan alam, panjang garis pantai), luas wilayah, jumlah penduduk, karakter bangsa yang selaras dengan kelautan, dan karakter pemerintah yang berorientasi ke laut. Ketika enam syarat tersebut terpenuhi, barulah negara dapat berfokus membangun kekuatan militer sebagai elemen kunci dari sea power (Mahan, 2014). Jika mengacu pada AS, nilai kegunaan sea powersangat besar hingga sebuah negara mampu mengontrol sikap negara lain pada masa perang maupun damai. Sea power yang dimiliki AS, dengan Angkatan Laut sebagai ujung tombaknya, telah lama memberi AS keistimewaan tersebut. Pada masa perang, kekuatan Angkatan Laut AS yang tersebar di seluruh jalur perdagangan dunia dapat menutup jalur distribusi yang menentukan kelangsungan hidup negara musuh. Hal ini membuat AS mampu melakukan tekanan militer langsung terhadap musuh sekaligus menghalangi musuh untuk melakukan tekanan yang sama terhadap kepentingan nasional AS. Pada masa damai, kekuatan tersebut mampu mendikte sistem perdagangan internasional sekaligus menjamin keberlangsungannya. Belum lagi jangkauan yang dimiliki oleh Angkatan Laut AS hingga dapat menangani berbagai kasus kejahatan yang terjadi di perairan internasional seperti pembajakan.

Melihat peran krusial militer dalam upaya pembangunan sea power, terasa aneh jika melihat keinginan Indonesia untuk membangun sea power lewat ide Poros Maritim Dunia tetapi di sisi lain justru kurang memperhatikan pembangunan kekuatan militer. Padahal, militer memegang peran yang sangat penting karena mustahil untuk mengembangkan perekonomian dan mempertahankan kedaulatan serta melindungi kepentingan nasional dalam bidang maritim jika tidak memiliki unsur militer yang kuat yang berfungsi melindungi, mengontrol, dan mengawasi keamanan negara di bidang maritim. Oleh karena itu, jika berkaca dari Tiongkok, Indonesia harus lebih dulu membangun militernya untuk kemudian menjadikannya sebagai pendukung sekaligus pelindung dari setiap kebijakan maritim dan kepentingan nasional. 


\begin{tabular}{|l|c|c|c|}
\hline & $\begin{array}{c}\text { Amerika } \\
\text { Serikat }\end{array}$ & Tiongkok & Indonesia \\
\hline Kapal Induk & 10 & 1 & 0 \\
\hline Kapal Fregat & 8 & 57 & 12 \\
\hline Kapal Perusak & 62 & 21 & 0 \\
\hline Kapal Korvet & 0 & 27 & 20 \\
\hline Kapal Selam & 68 & 57 & 2 \\
\hline $\begin{array}{l}\text { Kapal Penyapu } \\
\text { Ranjau Laut }\end{array}$ & 11 & 40 & 8 \\
\hline
\end{tabular}

Tabel 1. Perbandingan Kekuatan Angkatan Laut Indonesia dengan Amerika Serikat dan Tiongkok ${ }^{10}$ (IISS The Military balance, 2017)

\section{PENUTUP}

Penanganan keamanan maritim dalam ide Poros Maritim Dunia masih belum dapat dikatakan ideal karena Jokowi terlalu memperhatikan aspek ekonomi dan masih belum lengkapnya elemen-elemen pendukung kebijakan maritim Indonesia. Mengingat keamanan maritim sebagai parameter keberhasilan dari sebuah pemerintahan negara yang berorientasi pada maritim, maka sudah sepatutnya Jokowi lebih menekankan fokus Poros Maritim Dunia kepada isu keamanan maritim yang dapat dimulai secara bertahap mulai dari penetapan sebuah Doktrin Maritim, pembentukan MDA, dan pembangunan kekuatan militer.

Jalan dan proses Indonesia menuju negara maritim yang kuat dan terpandang memang tidak mudah, tetapi hal tersebut dapat dilalui jika Indonesia dapat menjaga stabilitas keamanan perairannya dan wilayah perairan di sekitarnya dimana hal tersebut didukung oleh kebijakan maritim yang strategis

10 Alasan dipilihnya perbandingan kekuatan Angkatan Laut dengan Tiongkok dan Amerika Serikat (AS) adalah karena Tiongkok merupakan negara paling dominan di regional Asia dan sedang dalam proses membangun sea power, sementara AS merupakan negara yang mampu mengimplementasikan sea power yang mereka miliki dan menguasai domain maritim dalam skala global yang ditandai dengan kehadiran armada AL mereka di seluruh wilayah laut di dunia. dan peran militer yang kuat didalamnya. Keterlibatan militer adalah hal yang sangat penting karena mustahil untuk mengembangkan perekonomian dan mempertahankan kedaulatan serta kepentingan nasional dalam bidang maritim jika tidak memiliki unsur militer yang kuat yang berfungsi melindungi, mengontrol, dan mengawasi keamanan negara di bidang maritim

\section{DAFTAR PUSTAKA}

Antara News. (2014). Di EAS, Jokowi Beberkan Lima Pilar Poros Maritim Dunia. Dalam http://www.antaranews.com/berita/4640 97/di-eas-jokowi-beberkan-lima-pilarporos-maritim-dunia.

Buerger, Christian. (2015). What Is Maritime Security. Forthcoming in Marine Policy, pp. 3.

Djalal, Hasjim. (2012). Indonesia's Maritime Challenges and Priorities. Dalam Joshua H. Ho \& Sam Bateman. (eds.), Maritime Challenges and Priorities in Asia: Implications for Regional Security (pp. 61-71). New York: Routledge.

FKP Maritim. (2014). Peran Poros Maritim Dunia Dalam Meningkatkan Pengaruh Indonesia di Tingkat Internasional. Di http://www.fkpmaritim.org/peranporos-maritim-dunia-dalammeningkatkan-peran-indonesia-ditingkat-internasional/.

International Institute for Strategic Studies. (2017). The Military Balance. http://www.iiss.org/en/publications/mili tary\%20balance/issues/the-militarybalance-2017-b47b

Jurnal Maritim. (2014). Maritime Security, Tolak Ukur Pencapaian Good Maritime Governance.

http://jurnalmaritim.com/2014/11/mariti me-security-tolok-ukur-pencapaiangood-maritime-governance/.

Marsetio. (2013). Membangun Maritime Domain Awareness Guna Mendukung Keamanan Maritim dalam Perspektif 
TNI Angkatan Laut. Jurnal Pertahanan Desember 2013.3 (3): pp. 4-6.

Ho, Joshua \& Catherine Zara Raymond (Eds.). (2005). The Best of Times, The Worst of Times: Maritime Security in the AsiaPacific. Singapore: Institute of Defence and Strategic Studies

Indian Navy. (2016). Indian Maritime Doctrine.

Rubel, Robert. C. (2012). Naval and Economic Prosperity: The New Logic of Sea Power. London. The Corbett Centre for Maritime Policy Studies.

Salim. (2013). Konsep Doktrin Maritim dan Strategi Maritim Militer Indonesia.

Suryabrata, Sumadi. (2003). Metode Penelitian. Jakarta: PT Raja Grafindo Persada.

Suwarto, Bambang. (2013). Kolaborasi Keamanan Maritim Dalam Menjaga Stabilitas Nasional. Jurnal Pertahanan Desember 2013.3 (3): pp. 1-2.

Till, Geoffrey. (2004). Seapower: A Guide for Twenty-First Century. New York. Routledge.

Till, Geoffrey. (2012). The Historic Attributes of the Sea and Maritime Developments in Asia-Pacific. Dalam Joshua H. Ho \& Sam Bateman. (eds.), Maritime Challenges and Priorities in Asia: Implications for Regional Security (pp. 34-42). New York: Routledge. 